Egyptian Journal of Aquatic Biology \& Fisheries

Zoology Department, Faculty of Science,

Ain Shams University, Cairo, Egypt.

ISSN $1110-6131$

Vol. 23(2): 363-377 (2019)

www.ejabf.journals.ekb.eg

\title{
Bioaccumulation of Heavy Metals and Physiological/Histological Changes in Gonads of Catfish (Clarias gariepinus) inhabiting Lake Maryout, Alexandria, Egypt
}

\author{
Heba H. Abdel-Kader* and Mohamed H. Mourad \\ National Institute of Oceanography and Fisheries, Alexandria, Egypt \\ *Corresponding Author: hebaelalkamy3232@gmail.com
}

\section{ARTICLE INFO \\ Article History: \\ Received: April 29, 2019 \\ Accepted: May 15, 2019 \\ Online: May 18, 2019}

Keywords:

Lake Maryout

Clarias gariepinus

Heavy metals

Antioxidant enzymes

Sex steroids

Histopathology
ABSTRACT

The current study investigated the bioaccumulation of heavy metals, as well as, physiological and histological alterations, in gonads of Catfish (Clarias gariepinus) inhabiting the polluted location (main basin) and a relatively clean area (southwest basin) at Lake Maryout. A significant $(P<0.05)$ decrease was recorded in muscle total protein and lipid in fish collected from the main basin in comparison to the southwest basin. In contrast, a significant $(P<0.05)$ increase in muscle water content was detected in fish collected from the main basin. A significant $(P<0.05)$ decrease in LH, FSH, estrogen, and progesterone hormones, as well as the activities of the antioxidant enzymes catalase (CAT), glutathione peroxidase (GPx) and superoxide dismutase (SOD), were detected in fish collected from the main basin in comparison to the southwest basin. Histological observation of ovary showed lytic ovary with some stages of oocytes include early pre-vitologenic, atretic late pre-vitologenic, wide inter-follicular space and loose tunica albugenia. On the other side, testes pathologies showed completely disorganized lobule structure, accompanied by a reduced number or disappeared of germinal cells, increased interstitial space with reduced interstitial cells. In conclusion, this study confirmed that the main basin of Lake Maryout suffered from great pollution that affected completely on the fish population and the situation needs the rapid intervention of the Egyptian government to stop agricultural, industrial and health drainage in Lake Maryout by establishing treatment units before direct drainage in the Lake

\section{INTRODUCTION}

Millions of pounds of toxic chemicals are flushed into Egyptian waterways each year. According to recent records, Egyptian Delta Lakes (Maryout; Manzala; Edku and Borollus) are heavily polluted and unsafe for fishing (Annabi et al., 2013). Saad (2003) recorded that the levels of pollution in these Lakes are in the following order: Lake Maryout> Lake Manzalah> Lake Edku> Nozha Hydrodrome> Lake Brullus. Lake Maryout is now considered a major source of pollution to the Mediterranean Sea through El-Mex pumping station, which receives the surplus water from the Lake and disposes it to El-Mex Bay (EEAA, 2009). Lake Maryout receives most of its water from a heavily polluted drain (El-Qalaa drain). Therefore, it has changed from being the most productive fisheries resource to the least productive in a couple of decades. 
Lake Maryout has been divided artificially into five basins: The fishery, the northwest, the southwest, the west, and the main basin, which is the heavily polluted part of the Lake (Adham, 2002).

Heavy metals are what one might call "the unknown killers" since these probably cause and aggravate most health conditions in our bodies. These tiny pieces of metals easily embedded in body tissues as a result of the toxic environment we live in now (Abdullahi, 2013). Bioaccumulation of heavy metals in the aquatic environment poses a serious threat to biodiversity and human health (Annabi et al., 2013). Among heavy metals dispersed in the environment, lead $(\mathrm{Pb})$, cadmium $(\mathrm{Cd})$, mercury $(\mathrm{Hg})$, and arsenic (As) are widely dispersed in the environment. The problem of heavy metals accumulation in aquatic organisms including fish needs continuous monitoring and surveillance owing to the biomagnifying potential of toxic metals in the human food chain (Mohanty et al., 2013).

Several investigations had concerned with the effect of toxic heavy metals on the biochemical composition in gonads of fishes (Abou EL-Naga et al., 2005; Mohamed and Gad, 2008; Arafa and Ali, 2008; Yousafzai and Shakoori 2009; Padmini and Usha Rani, 2009; Carvalho et al., 2012); tissue histological structures (Mohamed and Gad, 2008; Ebrahimi and Taherianfard 2011) ; and accumulation of heavy metals in gonads of fishes (Ebrahimi and Taherianfard 2011; Osman, 2012; Vergilio et al., 2013). These studies confirmed that such low-level pollution caused an effect on reproduction either directly on the free gametes (sperm or ovum) or indirectly via accumulation in the reproductive organs, which are released into the water. Control of reproduction in fish is difficult and controlled by a wide range of factors, and low-level pollution have been affected any part of this pathway (Shafiei et al., 2009)

Therefore, the goal of this study was to investigate some biochemical composition, histological alterations, and bioaccumulation of heavy metals in gonads of Catfish, Clarias gariepinus caught from polluted location (main basin) and a relatively clean area (southwest basin) at Lake Maryout.

\section{MATERIALS AND METHODS}

\section{Fish sampling}

Samples of Clarias gariepinus were collected from the main basin and southwest basin (Lake Maryout) (length $25 \pm 5 \mathrm{~cm}$ and weight $118 \pm 5 \mathrm{~g}$ ) during May 2017. Fish were directly dissected to carry out physiological and histopathological examinations in gonads.

\section{Determination of Metal pollution index} (1997).

The metal pollution index (MPI) was calculated according to Usero et al.,

$$
\mathrm{MPI}=\left(\mathrm{M}_{1} \times \mathrm{M}_{2} \times \mathrm{M}_{3} \times \mathrm{M}_{4} \times \ldots \ldots \ldots \ldots \mathrm{M}_{\mathrm{n}}\right)^{1 / \mathrm{n}}
$$

Where $M_{n}$ is the concentration of metal (n).

In the present study, $\mathrm{Cd}, \mathrm{Pb}, \mathrm{Hg}$ and As were used to calculate the MPI.

\section{Heavy metals in tissue samples}

Concentrations of heavy metals were measured in gonads according to methods described by (Bervoets and Blust, 2003). Tissue samples were dried at $105^{\circ} \mathrm{C}$ for 48 hours and then grounded to a fine powder. The dried samples were digested in which $0.5 \mathrm{~g}$ (dry powder) was digested in a solution of nitric "acid (HNO3 - AR grade) $(5 \mathrm{ml})$ on a hot plate at $80-90^{\circ} \mathrm{C}$ until the sample becomes clear. After cooling, the solution was filtered and the filtrate was made up to a known volume 
G5ml with deionized distilled water. The concentrations of $\mathrm{Pb}, \mathrm{Hg}, \mathrm{Cd}$ and $\mathrm{As}$ in gonads were measured by Atomic Absorption Spectrophotometer (Perkin Elmer 3110, Waltham, MA, USA, model 1200 A) and the results were expressed in " $\mu \mathrm{g} / \mathrm{g}$ " of the dry weight of the tissue

\section{Determination of body composition}

Sample of $0.1 \mathrm{~g}$ of muscle was homogenized in a glass homogenizer for 3 minutes in $5 \mathrm{ml}$ saline then centrifuged at 3000 r.p.m for 10 minutes. The supernatant was used for determination of total protein content and total lipid in tissues according to Doughaday et al. (1952); Knight et al. (1972), respectively. Water content in tissues was determined according to methods described by Sidwell, (1970). Caloric values were determined by using conversion factors: $4.19 \mathrm{cal} / \mathrm{mg}$ for protein and $9.5 \mathrm{cal} / \mathrm{mg}$ for lipid according to Prosser and Brown, (1961).

\section{Hormone Analysis}

Blood samples were collected from the caudal vein of adult female fish into a clean, dry, sterile container. They was centrifuged at $3000 \mathrm{rpm}$ for 15 minutes and the serum was collected in (Eppendorf) capped sterile tubes which was kept frozen at $-20^{\circ} \mathrm{C}$ till assaying FSH, LH, estradiol, and progesterone (Ebrahimi., 2004). They were quantitatively determined using fish enzyme-linked immunosorbent assay (ELISA) kits- (Sunlong biotech Co, Ltd), used Sandwich ELISA.

\section{Determination of Antioxidant enzymes}

The activity of glutathione peroxidase (GPX) (EC 1.11.1.9) was measured by The oxidation of NADPH to NADP ${ }^{+}$is accompanied by a decrease in absorbance at $340 \mathrm{~nm}$ (A340) providing a spectrophotometric means for monitoring GPx enzymes activity according to Paglia and Valentine (1967), but superoxide dismutase (SOD) (EC 1.15.1.1) activity was determined by the ability of the enzyme to inhibit the phenazine methosulphate -mediated reduction of nitroblue tetrazolium dye according to Nishikimi et al. (1972). While, catalase (CAT) (EC 1.11.1.6) activity was determined by the destruction of the $\mathrm{H}_{2} \mathrm{O}_{2}$ concentration at $240 \mathrm{~nm}$ according to Abei, (1984).

\section{Histopathological Examinations}

The light microscopic examinations were reported according to Bancroft and Gamble (2002). Tissue samples of gonads were quickly removed, fixed in $10 \%$ formalin solution and routinely processed for paraffin embedding. Sections were cut at $5 \mathrm{~mm}$ and stained routinely with Haematoxylin and Eosin (H\&E).

\section{Statistical analysis}

The data were analyzed by one-way ANOVA using the Statistical Processor System Support (SPSS 20, Armonk USA). Data are expressed as means \pm SD. Values of $P<0.05$ were considered statistically significant. Means in each row are significantly different $(P<0.05)$ with no common superscripts.

\section{RESULTS AND DISCUSSION}

\section{Bioaccumulation of heavy metals in gonads}

In this study, the concentrations of heavy metals in gonads of C. gariepinus collected from the main basin and the southwest basin are shown in Table (1). Metal pollution index for testes and ovary in the main basin were 1.762 and 1.756 respectively, while in southwest basin were 0.738 and 0.646 , respectively. In general, fish ovary compared to testes contains the lowest level of metals. The obtained results are in accordance with Honda (1983) who reported that relatively high concentrations of $\mathrm{Cd}$ and $\mathrm{Hg}$ were found in the testes in comparison to the ovary of 
Pagothenia boechgreninki. In this study, the mean $\mathrm{Pb}$ concentrations in gonads showed a highly significant increase $(P<0.05)$ of the studied fish in the main basin compared to the southwest basinLead is also known to damage the brain, the central nervous system, kidneys, liver and the reproductive system (Ademoroti, 1996).

Table 1: Metal concentration in gonads of Clarias gariepinus from the main basin and the southwest basin at Lake Maryout.

\begin{tabular}{clcr}
\hline $\begin{array}{c}\text { Metals } \\
(\boldsymbol{\mu g} / \mathbf{g} \text { dry weight })\end{array}$ & \multicolumn{1}{c}{ Location } & Testes & Ovary \\
\hline Lead & Main Basin & $3.44 \pm 0.54^{\mathrm{b}}$ & $3.42 \pm 1.10^{\mathrm{b}}$ \\
& Southwest Basin & $1.40 \pm 0.30^{\mathrm{a}}$ & $1.25 \pm 0.20^{\mathrm{a}}$ \\
\hline Mercury & Main Basin & $1.53 \pm 0.50^{\mathrm{b}}$ & $1.46 \pm 0.30^{\mathrm{b}}$ \\
& Southwest Basin & $0.45 \pm 0.60^{\mathrm{a}}$ & $0.40 \pm 0.10^{\mathrm{a}}$ \\
\hline Cadmium & Main Basin & $2.06 \pm 0.40^{\mathrm{b}}$ & $2.05 \pm 0.20^{\mathrm{b}}$ \\
& Southwest Basin & $1.07 \pm 0.10^{\mathrm{a}}$ & $0.83 \pm 0.20^{\mathrm{a}}$ \\
\hline Arsenic & Main Basin & $0.84 \pm 0.20^{\mathrm{b}}$ & $0.84 \pm 0.14^{\mathrm{b}}$ \\
& Southwest Basin & $0.44 \pm 0.09^{\mathrm{a}}$ & $0.42 \pm 0.14^{\mathrm{a}}$ \\
\hline
\end{tabular}

Values are expressed as mean $\pm \mathrm{SD},(\mathrm{n}=5)$. Means in a row with no common superscripts are significantly different $(P<0.05)$.

On the other hand, the mean $\mathrm{Hg}$ concentrations in tests and ovary showed also a highly significant increase $(P<0.05)$ of the studied fish in the main basin compared to the southwest basin. Mercury is one of the most toxic elements among the studied heavy metals and exposure to a high level of this element could permanently damage the brain, kidneys and developing fetus (Castro-González and Méndez-Armenta, 2008). Also, Cd concentrations in tests and ovary showed a highly significant increase $(P<0.05)$ of the studied fish in the main basin compared to the southwest basin. Cd toxicity in human may affect some organs such as kidney, lung, bones, as well as the central nervous system (Castro-González and Méndez-Armenta, 2008). Finally, the mean (As) concentrations in tests and ovary showed a highly significant increase $(P<0.05)$ of the studied fish in the main basin compared to the southwest basin. Arsenic is the most toxic element and considered as a Group (A) human carcinogenic followed by damage of lung, kidney, and skin (ATSDR, 2003). The concentrations of the studied heavy metals in gonads of Clarias gariepinus were found to be within unsafe limits as suggested by various authorities (FAO/WHO, 2004; EC, 2006) and indicated of pollution. From the above, we can see that, although these data may be not fully representative for the most recent situation, they still should provide a strong warning to the Egyptian population and authorities regarding the quality of fish. Our results were similar to the results of Ebrahimi and Taherianfard (2011) who studied the accumulation of heavy metals $(\mathrm{Pb}),(\mathrm{Cd}),(\mathrm{Hg})$, and (As) in cyprinid fish from the Kor River and reported that no significant differences $(p>0.05)$ were detected between the two sexes and species, which may be due to a similar degree of accumulation in both sexes and species, as their feeding habits and habitats are similar (Singh et al., 2006). Osman, (2012) studied the River Nile Pollution using Nile Tilapia fish and showed that the Nile tilapia sampled from the downstream river of the Nile accumulated higher levels of all the detected heavy metals than those collected from upstream sites.

\section{Biochemical composition}

Proximate body composition is a good indicator of fish physiological condition and health (Saliu et al., 2007). Variations of protein, lipid, energetic values and water content of Clarias gariepinus collected from the main basin and the southwest basin at Lake Maryout are shown in Table (2). Overall, a significant difference $(P<0.05)$ 
was observed in the chemical composition of Clarias gariepinus. Analysis of fish muscles showed that the highest protein and lipid contents value was recorded in fish caught from the southwest basin, respectively. In contrast, the lowest concentrations of protein and lipid were observed in fish caught from the main basin, respectively.

Table 2: Body compositions of Clarias gariepinus from the main basin and the southwest basin at Lake Maryout.

\begin{tabular}{lcc}
\hline \multicolumn{1}{c}{ Parameter } & Main Basin & Southwest Basin \\
\hline Total protein $(\mathbf{m g} / \mathbf{g})$ & $56.00 \pm 8.30^{\mathrm{b}}$ & $72.00 \pm 4.90^{\mathrm{a}}$ \\
Total Lipid $(\mathbf{m g} / \mathbf{g})$ & $26.00 \pm 5.00^{\mathrm{b}}$ & $32.00 \pm 3.50^{\mathrm{a}}$ \\
Total calories $(\mathbf{c a l} . / \mathbf{g})$ & $483.54 \pm 63.58^{\mathrm{b}}$ & $609.26 \pm 45.63^{\mathrm{a}}$ \\
Water content $(\%)$ & $75.00 \pm 4.40^{\mathrm{b}}$ & $53.00 \pm 7.70^{\mathrm{a}}$ \\
\hline Values are expressed as mean $\pm \mathrm{SD},(\mathrm{n}=5)$. Means in a row with no common superscripts are \\
significantly different $(P<0.05)$.
\end{tabular}

On the other side, the highest water content was recorded in the main basin, while the lowest was in the southwest basin. Similar to the above results, the energetic values were recorded in fish caught from the southwest basin (609.26 cal./g), while in the main basin, it was (483.54 cal./g). Also, Authman et al. (2013) reported that the muscle total protein contents of fish collected from El-Rahawy drain showed a highly significant decrease, while muscles water content was increased as compared with the values of the river Nile fish. The elevation in the lipid content observed in the muscles of Clarias gariepinus from the southwest basin could be the result of enhanced lipid synthesis and/or reduced utilization as like as the results observed by Mohamed and Gad (2008). While, the current results were disagreement with Palaniappan et al. (2008) that recorded depletion in lipid and protein contents in musculature of Catla catla exposed to lead may be due to tissue organization and their utilization in cell repair with the formation of lipoproteins, which are important cellular constituents of cell membranes and cell organelles present in cytoplasm. (Filipovic and Raspor, 2003). Moreover, the significant changes in fish body composition in the main basin and the southwest basin may be due to differences in water quality, feeding conditions, sex, maturity state, environmental conditions and the period during which the organism was captured (Saeed, 2013; Younis et al., 2014).

\section{Hormone Analysis}

The concentration of FSH, LH, estrogen and progesterone hormones of female Clarias gariepinus collected from the main basin and the southwest basin at Lake Maryout are shown in Table (3). A significantly $(P<0.05)$ increased in these hormones were recorded in fish caught from the southwest basin. The trends of these hormones were similar to the findings by Zhang et al. (1995) studied the effect of lead on reproductive endocrine function in pregnant rats. Samarawickrema et al. (2008) explained that the decrease in the concentration of LH and FSH may be due to direct action of cypermethrin on anterior pituitary gonadotrophs, responsible for the secretion of LH and FSH; or hypothalamic neurons, responsible for the secretion of gonadotropin-releasing hormone $(\mathrm{GnRH})$ that exercises tropic action on anterior pituitary gonadotrophs. Our results were an agreement with Thomas (1990) who recorded a significant decrease in plasma estrogen of Atlantic croaker after exposing fish to lead. The same results were recorded by Saxena et al. (1989) after exposing Asian swamp eel (Monopterus albus) to cadmium.

Ebrahimi and Taherianfard (2011) recorded that the concentration of estradiol in female fish in Band-e-Amir and Korbal village in both sexes of cyprinid fish from the Kor River were significantly decreased, while decreased of progesterone in 
Doroudzan-Dam from the Kor River fish showing the direct effect of heavy metal contamination on steroidogenesis in female fish, either due to the harmful effects of metals on either the hypothalamus-pituitary axis (Song et al., 2002) or on the germinal cells capacity of estradiol production (Hinck et al., 2007).

Also, Mohamed and Gad (2008) showed the heavy metals may have direct effects on fish gonads (testes and ovaries), resulting in a disturbing development of germ cells. Moreover, Heckers et al., (2002) found that exposure of fish in the Elbe River Germany exposed to heavy metals having endocrine disruptor effects leading to a decrease in the levels of sex steroid hormones. Agrawal (2012) and Salim (2015) suggested also that heavy metals can modify hormone production and activity through the blocking the synthesis of hormones, mimicking the natural hormones, and providing receptors that inhibit cell synthesis of hormones. Heavy metal toxicity in natural water is the major source of contamination, which have adverse effects of on the hypothalamic-pituitary-gonadal relationship of fish and disturbs the aquatic biodiversity that is responsible for maintaining and supporting overall environmental health (Drevnick and Sandheinrich (2003).

Table 3: Hormone analysis of Clarias gariepinus from the main basin and the southwest basin at Lake Maryout.

\begin{tabular}{clc}
\hline Hormone & Main Basin & Southwest Basin \\
\hline FSH $(\mathbf{I U} / \mathbf{m l})$ & $0.89 \pm 0.17^{\mathrm{b}}$ & $1.75 \pm 0.30^{\mathrm{a}}$ \\
LH $(\mathbf{I U} / \mathbf{m l})$ & $0.48 \pm 0.17^{\mathrm{b}}$ & $1.10 \pm 0.20^{\mathrm{a}}$ \\
Estrogen $(\mathbf{n g} / \mathbf{m l})$ & $103.40 \pm 24.2^{\mathrm{b}}$ & $182.80 \pm 57.76^{\mathrm{a}}$ \\
Progesterone $(\mathbf{n g} / \mathbf{m l})$ & $0.61 \pm 0.20^{\mathrm{b}}$ & $1.49 \pm 0.80^{\mathrm{a}}$ \\
\hline
\end{tabular}

Values are expressed as mean $\pm \mathrm{SD},(\mathrm{n}=5)$. Means in a row with no common superscripts are significantly different $(P<0.05)$.

\section{Antioxidant enzymes}

Antioxidant enzymes believed to play a very important role in the body defense system against reactive oxygen species (ROS), which are harmful products generated during normal aerobic respiration. As shown in Table (4) marked significant $(P<$ 0.05 ) decreases in catalase (CAT), glutathione peroxidase (GPX) and superoxide dismutase (SOD) activities were observed in Clarias gariepinus collected from the main basin comparing with the southwest basin. The obtained results are in agreement with Saliu and Bawa-Allah (2012) that showed a reduction in the activities of SOD and CAT in fishes Clarias gariepinus exposed to lead. Also, Vutukuru et al. (2006) showed decreased antioxidant activities of superoxide dismutase, catalase and lipid peroxidation in copper treated the freshwater teleost fish, Esomus danricus. Moreover, Sujatha et al (2011) showed decreased activities of CAT, GPX, and SOD in rats exposed to lead acetate.

CAT is responsible for the reduction of hydrogen peroxide, while GPx catalyzes the reduction of both hydrogen peroxide and lipid peroxides. However, our results indicated that the decreased of the GPx and SOD activities in tissues of the $C$. gariepinus, from the main basin, could be indicated that the abilities to protect against hydrogen peroxide were reduced and are not scavenged by these antioxidant enzymes. In addition, the marked decrease in SOD activity may result from direct binding of the metal to the enzyme leading to oxidative stress and lipid peroxidation (Bainy, 1993; Hamed et al., 2003). Low levels of GPx in fish may result in a significant accumulation of the high levels of $\mathrm{H}_{2} \mathrm{O}_{2}$. This could be associated to the $\mathrm{O}_{2}^{-}$production or to the action of metals on enzyme synthesis (Padmini and Usha Rani, 2009), and causing a number of cellular damage for the reason that the impairment in the radical formation. 
Table 4: The activities of the antioxidant enzyme (U/ml) of Clarias gariepinus from the main basin and the southwest basin at Lake Maryout.

$\begin{array}{ccc}\text { Antioxidant enzyme } & \text { Main Basin } & \text { Southwest Basin } \\ \text { Catalase } & 17.80 \pm 5.50^{\mathrm{b}} & 45.60 \pm 7.70^{\mathrm{a}} \\ \text { Glutathione peroxidase } & 18.60 \pm 6.50^{\mathrm{b}} & 52.40 \pm 7.70^{\mathrm{a}} \\ \text { Superoxide dismutase } & 31.20 \pm 5.80^{\mathrm{b}} & 72.40 \pm 11.50^{\mathrm{a}}\end{array}$

Values are expressed as mean $\pm \mathrm{SD},(n=5)$. Means in a row with no common superscripts are significantly different $(P<0.05)$.

\section{Histopathological alterations \\ Ovary}

In the present study, the histology of ovaries of C. gariepinus collected from the main basin of Lake Maryout showed lytic ovary with some stages of oocytes including early pre-vitologenic, atretic late pre-vitologenic, wide inter-follicular space and loose tunica albugenia (Fig. 1). Groups of deformed late pre-vitologenic oocytes with a gradual degeneration, as a centrically aggregated nucleoli in the disintegrating nucleus (Fig. 2). The atretic follicles were present throughout the year, but they were increasing during autumn (spent ovaries) and winter (resting ovaries); and these atretic follicles determined the spawned individuals (Emam and Badia, (2014). The pre-vitellogenic follicles found all over the year, but in autumn were abundant as the spent ovaries and in winter as the resting ovary and less common during spring and summer (spawning seasons) (Emam and Badia., 2014). In this study, atresia may be due to environmental stress (Mehta et al., 2015). Heavy metals pollution cause greater loss to advance stages of oogenesis (Raksha and Sharma. 2012). These effects may disturb the oogenesis and may reduce the ability of the fish to reproduce (Mehanna, 2005). Wahbi and El-Greisy (2007) recorded that in females Siganus rivulatus, effluents (industrial, mixed and domestic) resulted in extensive necrosis of oolema, hypertrophy, and hyperplasia of the follicular cells of oocytes. Also, ovaries showed atresia in the large vacuolated mature follicles where atresia characterized by broken zona radiata, the proliferation of follicular cells and break down of yolk granules. Abou Shabana et al. (2008) observed that oogenesis is disrupted on applying concentrations $(3.12 \%, 6.25 \% \& 12.5 \%)$ for, 7,14 and 28 days to the wastewater effluent. Atretic oocytes and degenerated follicles are observed lead to the absence of ripe oocytes. Nuclear disintegration is detected in perinucleolus oocytes, infiltration of blood tissue which disturbs the development of chromatin nucleolus and perinucleolus oocytes. While, exposure to low concentration doses for short duration resulted in nuclei disintegraion, pycnosis in perinucleolus oocytes and hyperplasia of granulosa layer and zona radiata. Inhibition of reproduction of catfish is caused by trace element accumulation, which inhibits gonadal development (Yamaguchi et al., 2007). While, ovaries of C. gariepinus collected from the southwest basin showed group-synchronous oocytes; early previtellogenic with small cytoplasmic volume, many late pre-vitellogenic, abundant cortical follicles with cortical alveoli, vitellogenic oocytes and post- vitellogenic oocytes (Fig. 3). Moreover, Yolk globules are observed at vitellogenic oocytes frequently fill the entire center of the oocyte, cortical alveoli coated by demarcated theca folliculi consist of follicular epithelium, granulosa and zona radiata well attached to the basement membrane of the oocyte, late pre-vitellogenic with many pleiomorphic nucleoli bordering the nuclear envelope inside the ooplasm (Fig. 4). These results conform to those reported by Abou Shabana et al. (2008); Cek and Yelmaz (2005). The mature or post-vitellogenic follicles were common during spring 
and summer as they were in the spawning and ready to spawn and ovulate (Raksha and Sharma, 2012).

Testes

The present results showed testes of C. gariepinus collected from the main basin of Lake Maryout with completely disorganized lobule structure, accompanied by a reduced number of, or the absence of, germinal cells, increased interstitial space with reduced interstitial cells (Fig. 5). Also, seminiferous tubules showed highly vacuolation and all developmental stages; spermatogonia, spermatocytes cyst, spermatid cyst showed spongy vacuolation (Fig. 6). Severe testicular atrophy with arrested spermatogenesis, necrotic spermatogenic cells, and vacuolization in the interstitial tissue Permanent testicular damage resulted from increasing degree levels of heavy metal accumulation (Hanna et al.,2008). Shan et al. (2009) observed slight degeneration of germ cells lining seminiferous tubules with desquamation of germ cells and the tubular lumen were filled with degenerated germ cells. Also, interstitial spaces were abnormally widening with degeneration of Leydig cells after the rat testes treated with lead. Also, El-Sayed et al. (2015) showed that lead acetate caused necrosis of spermatogenic cells in the rat's seminiferous tubules, congestion of interstitial blood vessels and severe interstitial edema. The testes of C. gariepinus collected from the southwest basin showed seminiferous tubules supported by thin connective tissue (Fig. 7), spermatogonia stage, spermatocytes cyst, spermatid and the lumen filled with more amounts of spermatozoa (Fig. 8). The annual reproductive cycle of testes in teleost fish is dependent on environmental conditions such as temperature that determines the time and duration of the spawning period (Krol et $a l ., 2006)$. Annual reproductive cycles of testes can be divided into spring, spring summer or autumn ones (Abou Shabana et al., 2008). The tunica albuginea of ovary and testes with no uniform thickness throughout the year but, it reached a high thickness during winter and became thin during spring and summer because of pressure exerted on it by the distended testicular lobules or enlarged mature follicles, and began to increase again during autumn (El-Morshedi et al. 2014). The spermatids increased during spring to produce spermatozoa and became few during summer as most of them were changed into spermatozoa. The spermatozoa began to appear within the lumen of testicular lobules during spring.

\section{CONCLUSION}

It is concluded that this study confirmed that the main basin of Lake Maryout suffered from great pollution that affected completely on the fish population. So, the situation needs rapid recovery from the Egyptian government to stop that agricultural, industrial and health drainage disposes of in Lake Maryout by establishing treatment units before direct drainage in the lake

\section{COMPETING INTERESTS}

Authors have declared that no competing interests exist.

\section{REFERENCES}

Abdullahi, M.S. (2013). Toxic effects of lead in humans: An overview global advanced research. J. Environ. Sci. Toxicology. 2(6): 157-162

Abei, H. (1984). Catalase in vitro. Methods enzymes. (105):121-126. doi: $10.1016 /$ S0076-6879 (84)05016-3 
Abou EL-Naga, E.H.; EL-Moselhy, K.M. and Hamed, M.A. (2005). Toxicity of cadmium and copper and their effect on some biochemical parameters of marine fish Magill seheli. Egyptian. J. Aquat. Res., 31(2): 60-71.

Abou Shabana, N.M.; Abdel-Moneim, A.M.; Khadre, S.E.M; and Elalkamy, H.H. (2008). Histological alterations in gonads of (Clarias lazera) after exposure to dyestuff and chemicals waste water effluent. Egypt. J.Aquat.Res. 34: 351-368.

Ademoroti, C.M.A. (1996). Environmental Chemistry and Toxicology. Foludex Press Ltd, Ibadan

Adham, K.G. (2002). Sublethal effects of aquatic pollution in Lake Catfish, (Clarais gariepinus). J. Appl. Ichthyology. 18:87-94. doi: 10.1046/j.14390426.2002.00337.x

Agrawal, A. (2012). Toxicity and Fate of Heavy Metals with Particular Reference to Developing Fetus Advances in Life Sciences. 2(2): 29-38. doi: 10.5923/j.als.20120202.06

Annabi, A.; Said, Kh. and Messaoudi, I. (2013). Cadmium: Toxic effects and physiological impairments in fishes. Int. J. of Adv.1 (4):60-79.

Arafa, M. M. and Ali, A. T. (2008). Effect of some heavy metals pollution in Lake Mariout on (Oreochromis niloticus) fish. Egypt. J. Comp. Path. and Clinic. Path. 21(3):191 - 201.

ATSDR (2003). Toxicological Profile for Arsenic.US Department of Health and Humans Services, Public Health Human Services, Centers for Diseases Control, Atlanta.171). In: Wallace, K.B., (Ed.), Free Radical Toxicology. 442 p.23, 313-322.

Authman, M.M.N.; Ibrahim, S.A.; El-Kasheif, M. A. and Gaber, H. S. (2013). Heavy Metals Pollution and Their Effects on Gills and Liver of the Nile Catfish Inhabiting El-Rahawy Drain, Egypt. Global Veterinaria. 10 (2): 103-115. dosi.gv. 2013. 10.2.71226

Bainy, A.C.D. (1993). How to evaluate the safety chemical substances in aquatic environments. Ciência e Cultura, 45: 10-11.

Bancroft, J.D. and Gamble, M. (2002). Theory and practice of histological techniques. Neuro. Exp. Neurol. 67(6):633.

Bervoets, L and Blust, R. (2003). Metal concentrations in water, sediment and gudgeon (Gobio gobio) from a pollution gradient: relationship with fish condition factor. Environ Pollut. (126):9-19. Doi 10.1016/S02697491(03)00173-8.

Castro-González, M.I. and Méndez-Armenta, M. (2008). Heavy metals: implications associated to fish consumption. Environmental Toxicology and Pharmacology 26: 263-271. Doi 10.1016/j.etap.2008.06.001

Cek. E.K. and Yelmaz. E. (2005). Gonad Development and Sex Ratio of Sharptooth Catfish (Clarias gariepinus Burchell, 1822) Cultured under Laboratory Conditions. Turk. J Zool.31: 35-46.

Carvalho, C.d.S.; Bernusso, V. A.; Araújo, H. S. Sd; Espíndola, E. L. G. and Fernandes, M. N. (2012). Biomarker responses as indication of contaminant effects in Oreochromis niloticus. Chemosphere, 89:60-69. doi10.1016/j. chemosphere.2012.04.013

Doughaday, W.H.; Lowry, O.H. and Rosebrugh, N.J. (1952): Determination of cerebrospinal fluid protein with the folinephenol reagent. J. Lab. Clin. Med. 39: 663-665. 
Drevnick, P. E. and Sandheinrich, M. B. (2003). Effects of dietary methylmercuryon reproductive endocrinology of fatheadminnows. Envir. Sci. \&tech. 37(19). Doi 4390-4396. 10.1021/es034252m.

Ebrahimi, M. (2004). Setting up an Elisa method for steroid hormones. Ira. J. of Vet. Sci. (5): 30-55.

Ebrahimi, M. and Taherianfard, M. (2011). The effects of heavy metals exposure on reproductive systems of cyprinid fish from Kor River. Iranian Journal of Fisheries Sciences 10(1) 13-24

EC (2006). Setting maximum levels for certain contaminants in foodstuffs, No $1881 / 2006$ of 19 December 2006.

EEAA (2009). Alexandria Integrated Coastal Zone Management Project. AICZMPESIA.113.

El-Morshedi, N.; Alzahrani, I.; Kizilbash, N.A., Abdeen, A.; El-Shebbly, A.A. and El-Berri, A., (2014). Effect of heavy metal pollutants on fish population in two Egyptian Lakes. Int. J. Adv. 2(1): 408-417.

El-Sayed, M.F.B.; Sary, K.H.; Abdel-Ghafar, A.; Adly, M.A.; Salim, A.A. and Abdel-Samei, W.M. (2015). The ameliorative effects of DMSA and some vitamins against toxicity induced by lead in the testes of Albino rats. J. Basic. Appl. Zool. 71: 60-65.

Emam, A.N.M. and Badia, A. (2014). Seasonal histological changes in gonads of the catfish (Clarias lazera). Fisheries and Aquaculture Journal, 5, 1. doi: $10.4172 / 2150-3508.1000087$

FAO/WHO, (2004). Summary of Evaluations Performed by the Joint FAO/WHO Expert Committee on Food Additives (JECFA 1956-2003), (First Through Sixty First Meetings). ILSI Press International Life Sciences Institute.

Filipovic, V. and Raspor, S. (2003). Metallothionein and metal levels in cytosol of liver, kidney and brain in relation to growth parameters of Mullus surmuletus and Liza aurata. From the eastern Adriatic Sea. Water Res., 37(13): 32533262. Doi 10.1016/S0043-1354(03)00162-3

Hamed, R.R.; Farid, N.M.; Elowa, S.E and Abdalla, A.M., (2003). Glutathione related enzyme levels of freshwater fish as bioindicator of pollution. Environmentalist.23, 313-322.

Hecker, M.; Tyler, C.H.R.; Hoffman, M.; Maddix, S. and Karbe, L. (2002). Serum biomarkers in fish provide evidence for endocrine modulation in the Elbe River Germany. Environ. Sci. Technol. 36: 2311-2321. Doi: 10.1021/es010186h

Hanna, M.; Shaheed, L. and Elias, N. (2008): A contribution on chromium and lead toxicity in cultured Oreochromis niloticus. Egypt. J. Aquat. Biol. Fish., 9: 177209

Hinck, J. E.; Blazer, V. S.; Denslow, N. D.; Myers, M. S.; Gross, T. S. and Tillitt, D. E. ( 2007). Biomarkers of contaminant exposure in northern pike (esox lucius) from the yukon river basin, Alaska. Archives of Envir. Cont. and Toxi. 52(4), 549-562.

Honda, K.;Sahrul, M.; Hidaka, H.; and Tatsukawa, R. (1983). Organ and Tissue distribution of heavy metals, and Their growth-related Changes in Antarctic Fish, Pagothenia boechgreninki. Agricultural and biological chemistry. Clinical Chemistry, 75(3), 199. [Abs.]/10, 47(11), 2521-2532, Doi: 1080/00021369.1983.

Knight, A.; Anderson, S. and Rowle, J.M. (1972). Chemical basis of the sulfophosphovanillin reaction of estimating of total serum lipids. Clin. Chem. 75(3): 199 
Krol, J.; Glogowski, J.; Demska-Zakes, K. and Hliwa ,P. (2006). Quality of semen and histological analysis of testes in Eurasian perch Perca fluviatilis L. during a spawning period. Czech J. Anim. Sci., 51, (5): 220-226. Doi 10.17221/3932CJAS

Mehanna, S.F. (2005). Population dynamics and management of the Nile Tilapia $(O$. niloticus) in Wadi El-Raiyan lakes, Egypt. Afr. J. Biol. Sci. 1:79-88.

Mehta, M.; Mukesh, A. and Ambani, M. (2015). Effects of reproductive biology on heavy metal pollution on the histopathological structure of gonads in India Adv. Aquaculture. Fish. Manage. 3 (2): 223-227, February, 2015.

Mohamed, F. and Gad, N. (2008). Toxicological effects of three pesticides on the protein and lipid fish contents of tissues of Oreochromis niloticus. Egypt. J. Aquat. Biol. Fisher. (8): 111-133.

Mohanty, B. P.; Mahananda, M. R and Pradhan, S. (2013). Cadmium Induced Toxicity and Antioxidant Activities in Labeo Rohita (Hamilton) Environment and Ecology Research 1(2): 41-47. doi: 10.13189/eer.2013.010203

Mohamed, N . A.; Ali, A. M.; Bakhoum, S A.; Abdel-Kader, H H. and Ahmed, M. A. (2019) . Monitoring of Oxidative Stress Biomarkers and Toxicity of Lead and Mercury in Catfish of Lake Mariout, Egypt: The Role of Meso -2, 3Dimercaptosuccinic Acid (DMSA). Egyptian Journal of Aquatic Biology and Fisheries. 23(2): 165 - 182 . Doi: 10.21608/EJABF.2019.30238.

Nishikimi, M.; Roa, N.A.and Yogi, K. (1972). The occurrence of superoxide anion in the reaction of reduced phenazine methosulfate and molecular oxygen. Biochem. Biophys. Res. Commun. 1972;46:849-854. doi: 10.1016/S0006-291X(72)80218-3.

Osman, A.G.M. (2012). Biomarkers in Nile Tilapia (Oreochromis niloticus) to assess the impacts of river Nile pollution: Bioaccumulation, biochemical and tissues biomarkers. J. Environ. Prot. (3): 966-977. doi: 10.4236/jep.2012.328112.

Padmini, E. and Usha Rani, M. (2009). Evaluation of oxidative stress biomarkers in hepatocytes of grey mullet inhabiting natural and polluted estuaries. Sci. Total Environ. 407, 4533-4541. doi: 10.1016/j.scitotenv.2009.04.005.

Prosser, C. L., and F. A. Brown, Jr. 1961. Comparative animal physiology. 2nd ed. W. B. Saunders Company, Philadelphia. 688.

Palaniappan, R.M.; Sabhanayakam, S.; Krishnakumar, N. and Vadivelu, M. (2008). Morphological changes due to lead exposure and the influence of DMSA on the gill tissues of the freshwater fish (Catla catla). Food. Chem. Toxicol. 46, 2440-2444 doi:10.1016/j.fct.2008.03.028

Paglia, D.E. and Valentine, W.N. (1976). Studies on the quantitative and qualitative characterization of erythrocyte of glutathione peroxidase. J. Lab. Clin. Med., 7:158-169.

Raksha modi and Sharma. (2012). Histopathological study of effect of heavy metal pollutant $(\mathrm{CuSo} 4)$ on neurohypophysial complex and spewing period of female Anabas Testudineus .Bionano Frontier . 5, 2-1.

Saad, M.A.H. (2003). Impact of diffuse pollution on the socio-economic development opportunities in the coastal Nile Delta Lakes. Diffuse Pollution Conference Dublin ECSA. Management 5

Saeed, S.M. (2013). Impact of environmental parameters on fish condition and quality in Lake Edku, Egypt. Egypt. J. Aquat. Biol.Fish. 17 (1), 101-112. doi: 10.21608/EJABF.2013.2160 
Salim, F. (2015). Histopathological effect of heavy metal on different organs of fresh water fish tissues from Garmat Ali River adjacent to Al- Najebyia power station, Kufa J. For Vet. Med. Sci. 6 (1).

Saliu, J.K.; Joy, O. and Catherine (2007). Condition factor, fat and protein content of five fish species in Lekki Lagoon. Nigeria. Life Sci. J. 4, 54-57.

Saliu, J.K. and Bawa-Allah, K.A.(2012). Toxicological effects of lead and zinc on the antioxidant enzyme activities of post juvenile Clarias gariepinus. Resources and Environment , 2(1): 21-26 DOI: 10.5923/j.re.20120201.03

Samarawickrema, N.; Pathmeswaran, A.; Wickremasinghe R.; Peiris-John, R.; Karunaratna, M.; Buckley, N. and Dawson, A, de Silva. J. (2008). Fetal effects of environmental exposure of pregnant women to organophosphorus compounds in a rural farming community in Sri Lanka. Clin Toxicol (Phila). 46:489-495. Doi 10.1080/15563650701837030

Saxena, D. K.; Murthy, R. C.; Singh, C. and Chandra, S. V. (1989). Zinc protects testicular injury induced by concurrent exposure to cadmium and lead in rats. Research Communications In Chemical Pathology And Pharmacology, 64(2), 317-330.

Shan, G.; Tang, T. and Zhang, X. (2009). The protective effect of ascorbic acid and thiamine supplementation against damage caused by lead enzymes and lipid peroxidation products in developing rat brain. Biometals. 21(1): 9-16. DOI: 10.1007/s11596-009-0114-4

Sidwell, V.D.; Stallings, B.R. and Knobble, M.(1970). The fish protein concentration. Nutritional quality and using fish in foods. J. Food.Technol. (14): 40-46.

Singh, R. K.; Chavan, S. L. and Sapkale, P. H. (2006). Heavy metal concentrations in water, sediments and body tissues of red worm (tubifex spp.) collected from natural habitats in mumbai, india. Environmental Monitoring Assessment, 129(1-3), 471-481. Doi 10.1007/s10661-006-9377-4

Shafiei, S. S.; Imanpour, M.R.; Aminian, F. B. and Gorgin, S. (2009). Relation between gonadal hormones and sexual maturity of female kutum (Rutilus frisii kutum Kamenskii, 1901) during spawning season. J. cell and mol. Res., 1(2): 96-104.

Shah, S.L. (2006). Haematological parameters in tench (Tinca tinca) aftershort-term exposure to lead. J. Appl.Toxicol. 26(3): 223-228. Doi 10.1002/jat.1129

Song, Y.; Xu, H.; Ren, L.; Gong, P. and Zhou, Q.(2002). Eco-toxicological effects of heavy metals on the inhibition of seed germination and root elongation of chinese cabbages in soils. Huan Jing Ke Xue, 23(1), 103-107.

Sujatha, K.; Srilatha, C.H.; Anjaneyulu, Y. and Amaravathi, P. (2011). Lead acetate induced nephrotoxicity in Wistar Albino rats. A pathological, immunehistochemical and ultrasructural studies. Int. J. Pharm. Bio. Sci. 2(2):459-469.

Thomas, P. (1990). Teleost model for studying the effects of chemical on female reproductive endocrine function. Journal of experimental zoology, Suppl. 4, 126-128. Doi 10.1002/jez.1402560421

Usero, G.; Gonzales-Regalado, E.and Gracia, I. (1977). Trace metals in bivalve mollusks Ruditapes decussates and Ruditapes philippinarum from the atlantics Coast of the Southern Spain.Envirin.Int. 23:291-298

Vergilio, C.S.; Moreira, R.V.; Carvalho, C.E.V. and Melo, E.J.T. (2013). Histopathological Effects of Mercury on Male Gonad and Sperm of Tropical Fish Gymnotus carapo in vitro Web of Conferences. doi: $10.1051 / \mathrm{e} 3$ sconf/20130112004 
Vutukuru,S.S.; Chintada, S. Madhavi, K.R. ;Rao.J.V. and Anjaneyulu, Y., (2006). Acute effects of copper on superoxide dismutase, catalase and lipid peroxidation in the freshwater teleost fish,Esomus danricus. G.Fish PHysiol.Biochem.32:221-229. doi: 10.1007/s10695-006-9004-x.

Yamaguchi, S.;Miura, C.; Ito A., Agusa, T.; Iwatab, H.; Tanabe, S.; Cach Tuyen B. and Miura T. (2007). Effects of lead, molybdenum, rubidium, arsenic and organochlorines on spermatogenesis in fish: Monitoring at Mekong.Delta area and in vitro experiment. Aquat. Toxicology., 83: 43-54. doi: 10.1016/j.aquatox.2007.03.010

Younis, E.M.; Al-Asgah, N.A.; Abdel-Warith, A.A. and Al-Mutairi, A.A. (2014). Seasonal variations in the body composition and bioaccumulation of heavy metals in Nile tilapia collected from drainage canals in Al-Ahsa, Saudi Arabia. Saudi J. Biol. Sci. 22 (4),443-447. doi: 10.1016/j.sjbs.2014.11.020.

Yousafzai, A.M. and Shakoori, A.R. (2009). Fish white muscle as biomarker for riverine. Pollution Pakistan. J. Zool. 41(3):179-188.

Wahbi, O. M. and El-Greisy, Z. A. (2007). Comparative Impact of Different Waste Sources on the Reproductive Parameters and Histology of Gonads, Liver and Pituitary Gland of Siganus rivulatus. J. Appl. Sci. Res., 3: 236-244.

Zhang S.N.; Liu C.F.; Dong J.W.; Li X.J. and Xiang C.Q. (1995) Effect of lead on reproductive endocrine function in pregnant rats [J], Lao Dong Yi Xue, 12(2): 9-11. 

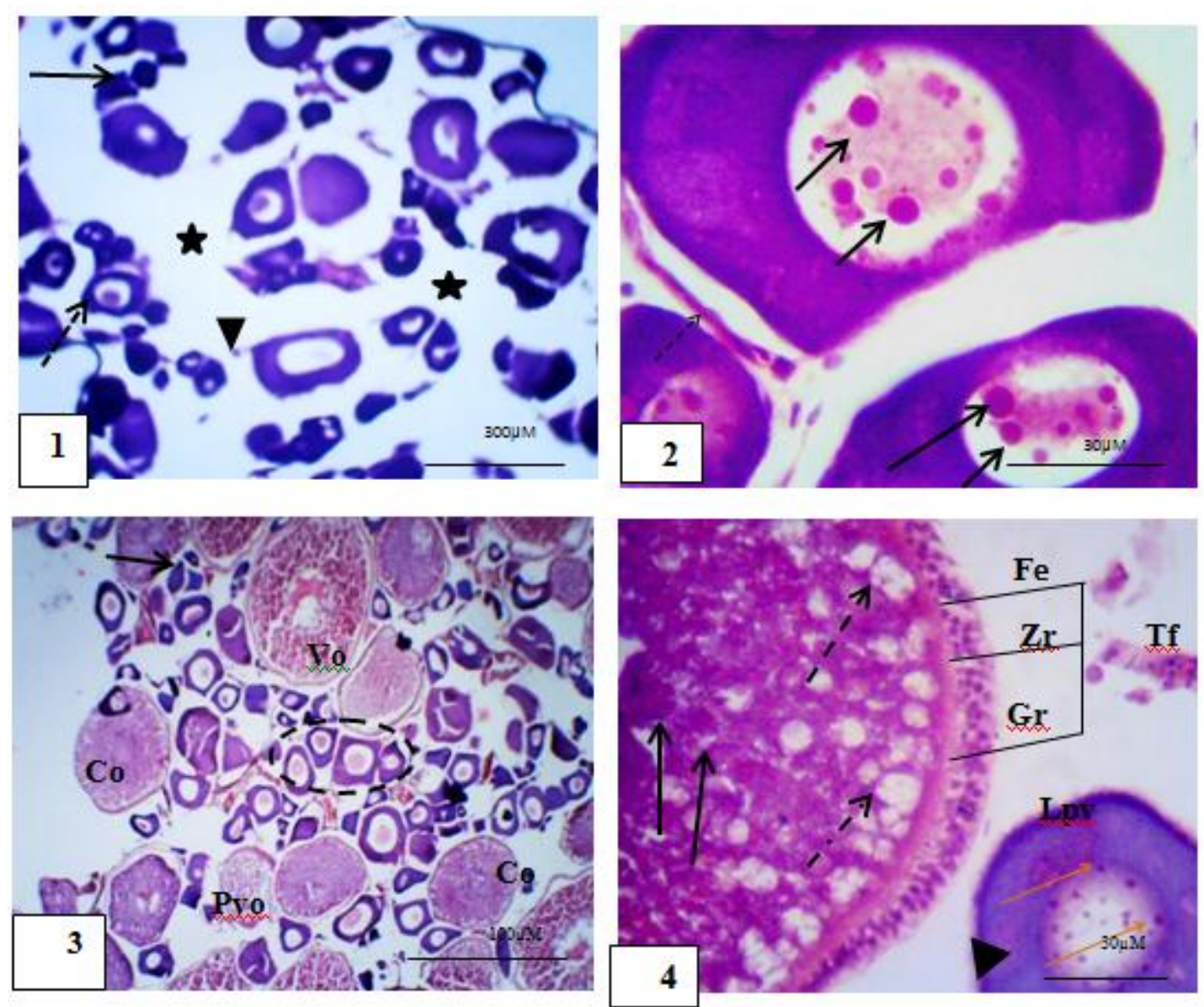

Fig. 1: Ovary tissues of C. gariepinus collected from the main basin showed lytic ovary with some stages of oocytes includes early pre-vitologenic (arrow), atretic late pre-vitologenic (dashed arrow), wide inter-follicular space (stars) and loose tunica albugenia (arrowhead) (5X. H\&E stain).

Fig..2: Ovary tissues of C. gariepinus collected from the main basin showed groups of deformed late previtologenic oocytes with a gradual degeneration, as a centrically aggregated nucleoli in the disintegrating nucleus (arrows) (40X. H\&E stain).

Fig. 3: Ovary tissues of C. gariepinus collected from the southwest basin showed group-synchronous oocytes, early pre-vitellogenic with small cytoplasmic volume (circle), many late pre-vitellogenic (dashed circle), abundant cortical follicles (Co) with cortical alveoli, vitellogenic oocytes (Vo), post- vitellogenic oocytes (Pvo) (10X. H\&E stain).

Fig. 4: Ovary tissues of C. gariepinus collected from the southwest basin showed part of vitellogenic oocytes includes yolk globules (arrows) frequently fill the entire center of the oocyte, cortical alveoli (dashed arrows) coated by demarcated theca folliculi (Tf) consist of follicular epithelium $(\mathrm{Fe})$, granulosa $(\mathrm{Gr})$ and zona radiata $(\mathrm{Zr})$ well attached to the basement membrane of the oocyte, late pre-vitellogenic (Lpv) with many pleiomorphic nucleoli (orange arrows) bordering the nuclear envelope inside the ooplasm (arrowhead ) (40X. H\&E stain). 

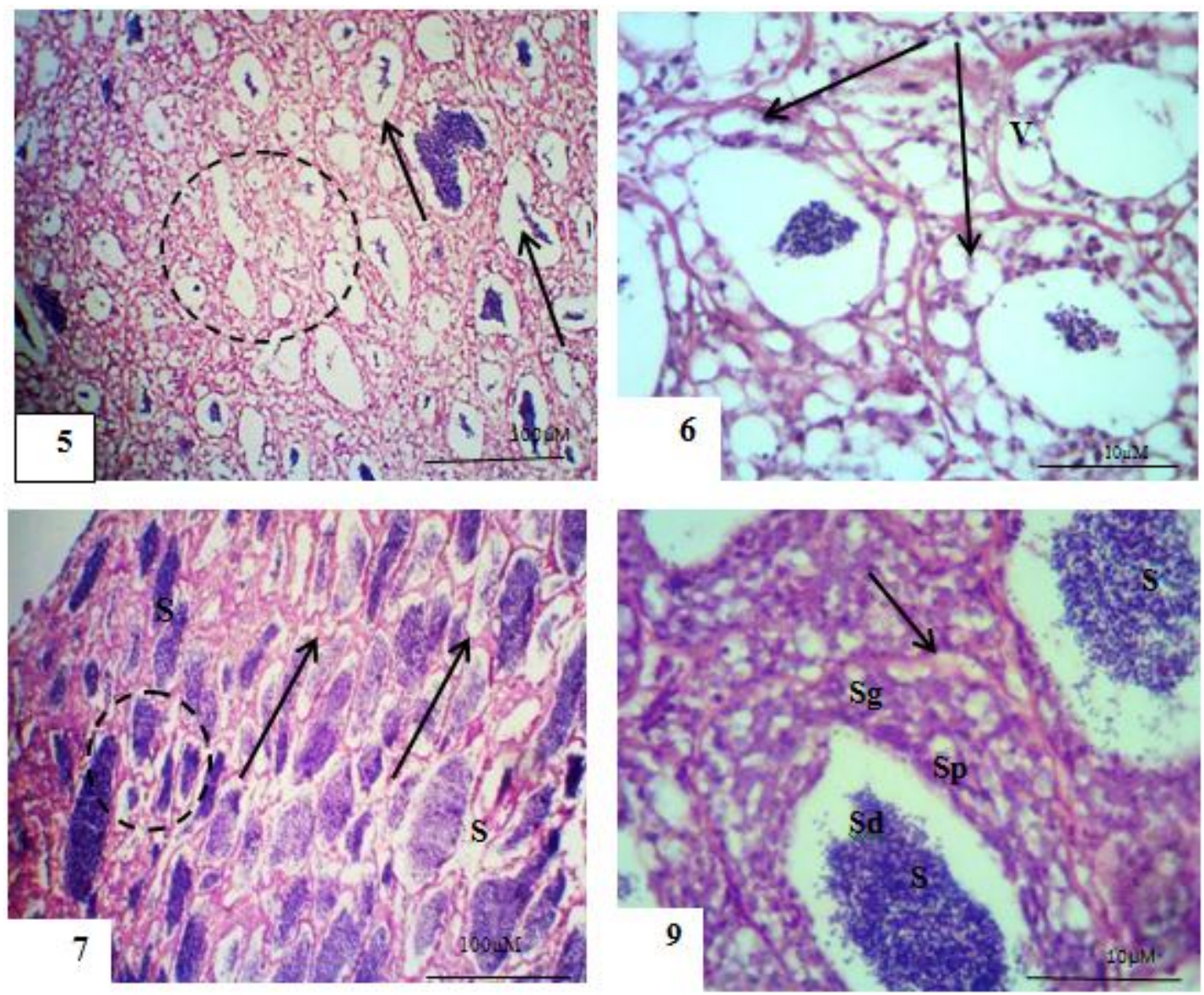

Fig. 5: Testes tissues of C. gariepinus collected from the main basin showed completely disorganized lobule structure accompanied by a reduced number (circle) of, or the absence of, germinal cells, increased interstitial space with reduced interstitial cells (asterisk) (10X. HE stains).

Fig. 6: Testes tissues of C. gariepinus collected from the main basin showed seminiferous tubule much affected with highly vacuolation. All developmental stages (spermatogonia, spermatocytes cyst, spermatid cyst) showed spongy vacuolation (40X. H\&E stain).

Fig. 7: Testes tissues of C. gariepinus collected from the southwest basin seminiferous tubules (St) supported by normal thin connective tissue accompanied with more amounts of spermatozoa (S) (10X. H\&E stain).

Fig. 8: Testes tissues of C. gariepinus collected from the southwest basin seminiferous tubules (St) supported by thin connective tissue (arrow), spermatogonia stage ( $\mathrm{Sg}$ ), spermatocytes cyst ( $\mathrm{Sp}$ ), spermatid (dashed-arrow), the lumen filled with spermatozoa (S) (40X. H\&E stain). 